\title{
A bumblebee new to the New World: Bombus distinguendus (Hymenoptera: Apidae)
}

\author{
Paul H. Williams ${ }^{1}$ \\ Department of Entomology, The Natural History Museum, South Kensington, London \\ SW7 5BD, United Kingdom
}

Jennifer C. Thomas

Snow Entomological Museum, University of Kansas, Lawrence, Kansas 66045-7523, United

States of America

\begin{abstract}
Bombus (Subterraneobombus) distinguendus Morawitz, 1869 is recorded from Attu Island, in the western Aleutian archipelago, and is recognised as a species new to both the Alaskan and the New World faunal lists. Colour variation and food plants are described and a key to females of Nearctic Subterraneobombus species is provided.
\end{abstract}

Résumé-Bombus (Subterraneobombus) distinguendus Morawitz, 1869 a été reporté dans l'île Attu, dans l'archipel Ouest Aleutien et est reconnu comme espèce nouvelle aux deux listes faunales de l'Alaska et du Nouveau Monde. Une description de la variation de la couleur et des plantes servant de nourriture ainsi qu'une clé des femelles des espèces Subterraneobombus du Néartique sont fournies.

\section{Introduction}

In 2002, an anthropological expedition collected the first recorded bumblebee from Attu Island, at the far western end of the Aleutian archipelago. The species was unexpected, because it was not among those recorded hitherto from the Aleutians (Table 1). This paper documents that find, describes further specimens, and recognises them as a species new to both the Alaskan and the New World faunal lists.

\section{Bombus (Subterraneobombus) distinguendus Morawitz}

(Figs. 1-2)

Bombus distinguendus Morawitz, 1869: 32.

Note: For a discussion of the nomenclature of this species, see Williams (1998).

\section{Material examined}

The first specimen, a queen, was collected by $\mathrm{H}$. Lanier from the expedition field camp at Austin Cove on the northern side of Attu Island (Aleutian Islands) on 18 August 2002. Between 8-22 July 2003, J.C.T. collected seven queens

Received 15 June 2004. Accepted 30 December 2004.

${ }^{1}$ Corresponding author (e-mail: paw@nhm.ac.uk). and nine workers near the Loran A Building at the southern end of Attu Island. All of the material from Attu Island is deposited in the Snow Entomological Museum, University of Kansas Natural History Museum, Lawrence, Kansas, United States of America (SEMC: six queens and seven workers), with the exception of two queens and two workers from 8-22 July, which are deposited in the collection of the Natural History Museum, London, United Kingdom (BMNH). Additional material of the species from elsewhere within its range was examined in collections of the BMNH and of P.H.W.

\begin{abstract}
Affinities
All of the bumblebees from Attu Island belong to the subgenus Subterraneobombus Vogt, 1911 (see the key in Michener 2000). Hitherto, two species of this subgenus have been known from North America: Bombus borealis Kirby, 1837 and Bombus appositus Cresson, 1878 (e.g., Franklin 1913; Milliron 1973; Kearns and Thomson 2001). No species of this group are known from South America, but there are at least seven species in the Old World (Williams 1998). Among the material of this group examined, the new specimens agree most closely with $B$. distinguendus, which has not been recorded previously from the New World except through the implication of conspecificity with
\end{abstract}


B. appositus (see below). We look forward to seeing a male bumblebee from Attu Island to check this identification.

Handlirsch (1888, p. 234) described B. appositus as the "amerikanische Form" of B. distinguendus. Similarly, Franklin (1913, p. 289) considered that $B$. appositus "is probably merely a variety" of $B$. distinguendus, and Milliron (1973, p. 115) considered that it "might be only a junior synonym". Nonetheless, all three authors listed these taxa as separate species.

\section{Diagnosis}

Queens of $B$. distinguendus can be distinguished from queens of both $B$. appositus and $B$. borealis by the sculpturing of the central area of tergum 6. For B. distinguendus, at least half of the breadth of tergum 6 is flat, smooth, and shining, except for broadly spaced punctures. For B. appositus and B. borealis, this area is coarsely granular and dull, with at most only a narrow longitudinal median band, smooth and shining.

Males of B. distinguendus (from Europe and Russia) are distinct from those of both $B$. appositus and $B$. borealis in their genitalia. This is particularly clear from the ventrolateral angle of the penis valve of $B$. distinguendus, which is produced into a narrower process that scarcely broadens distally. For B. appositus and $B$. borealis, the ventrolateral process broadens strongly distally, forming a shape like a duck's webbed foot.

\section{Colour variation}

The specimens of $B$. distinguendus from Attu Island are unusually dark. The queens have the pubescence of the face partly yellow and partly black. The pubescence of the sides of the thorax posteriorly, and of the lower half of the sides anteriorly, is predominantly black (Fig. 1), whereas these areas are yellow-grey among specimens from eastern Russia. In addition, six of the queens have a patch of black hairs in the middle of the base of metasomal tergum 5. Two queens also have smaller patches of black basally on all of the metasomal terga.

Among the workers, the variation is greater. All have the pubescence of the face predominantly black. However, they vary in the number of black hairs: one worker has no black hairs in the middle of tergum 5; most workers have many black hairs on tergum 5; and another

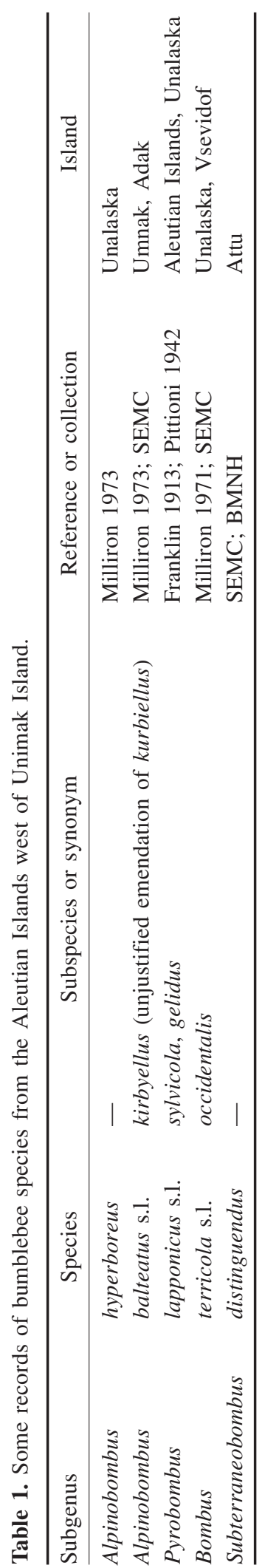

(C) 2005 Entomological Society of Canada 
Fig. 1. Photographs of a Bombus distinguendus queen collected from Austin Cove, Attu Island, on 18 August 2002. Left, dorsal aspect; right, left lateral aspect. The scale bar is marked in millimetres. Photo by Harry Taylor, BMNH.
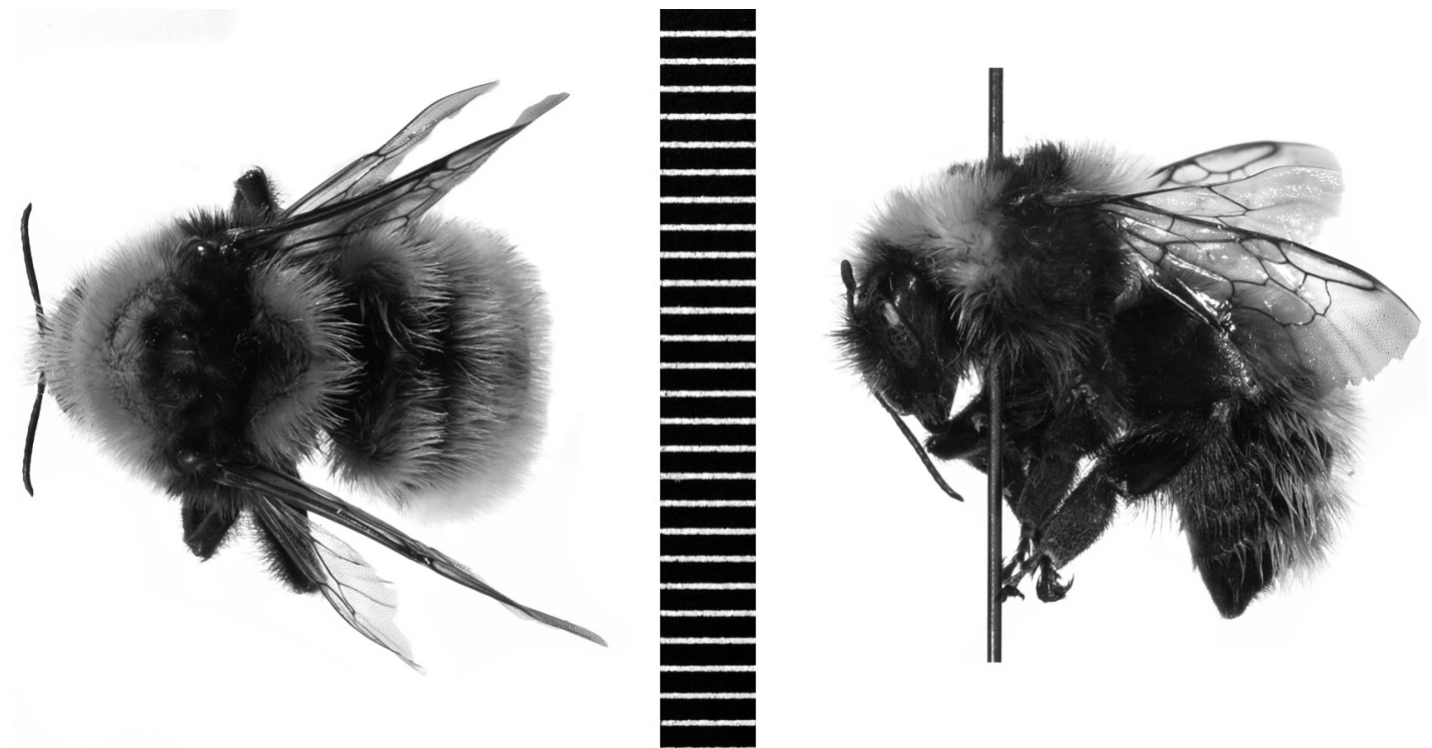

Fig. 2. Records of Bombus distinguendus for equal-area $\left(611000 \mathrm{~km}^{2}\right)$ grid cells: black spots (3) are for specimens identified by P.H.W.; grey spots (2) are for literature records; and white spots (1) are for expected distribution. Attu Island is the easternmost record. Grid cells are at intervals of $10^{\circ}$ longitude from $30^{\circ} \mathrm{W}$ at the left edge of the map, and the occupied cells are bounded at latitudes of $71^{\circ} 44^{\prime} \mathrm{N}, 59^{\circ} 41^{\prime} \mathrm{N}, 51^{\circ} 00^{\prime} \mathrm{N}, 43^{\circ} 41^{\prime} \mathrm{N}$, and $37^{\circ} 12^{\prime} \mathrm{N}$ (for further details, see Williams 1998).

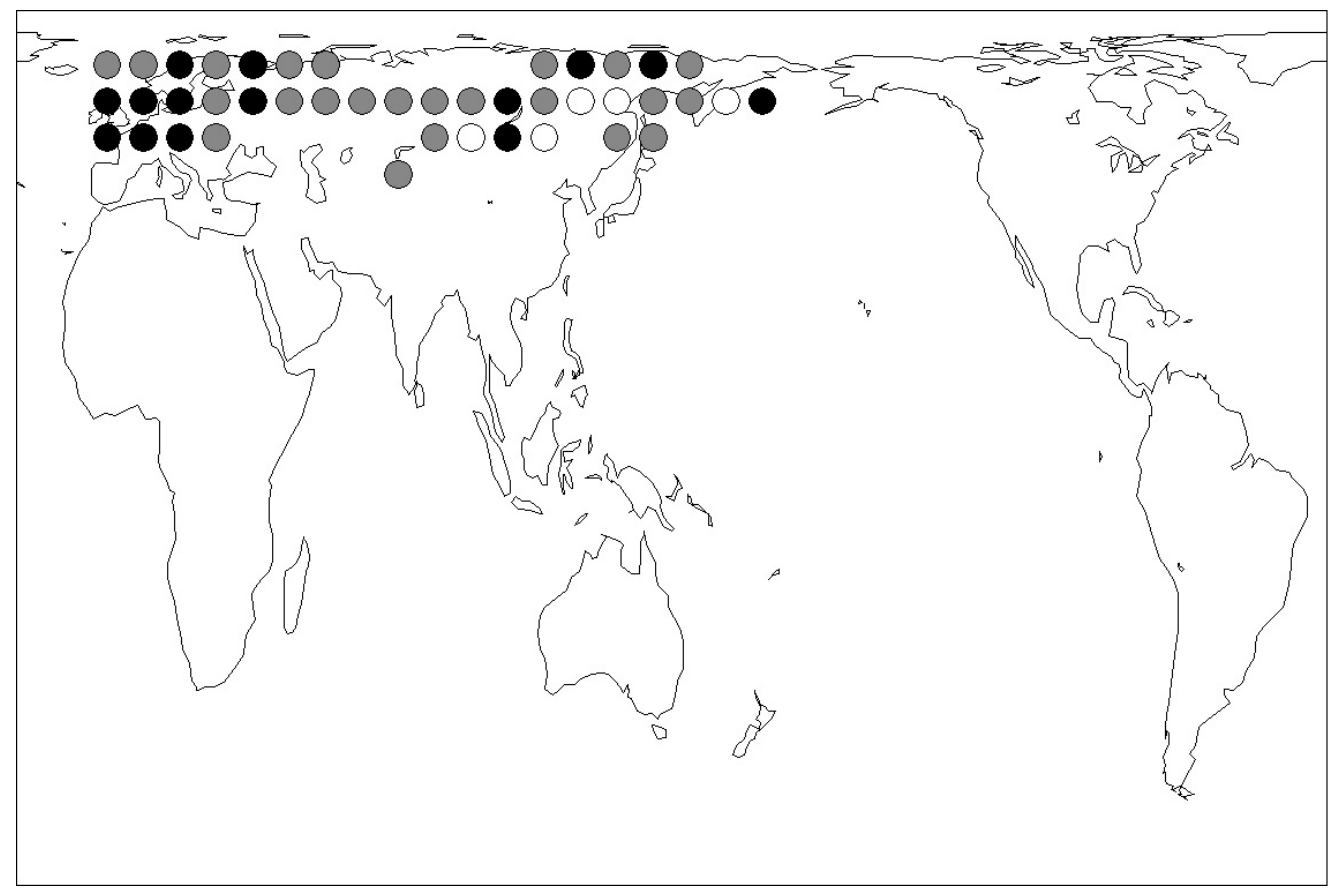

(C) 2005 Entomological Society of Canada 
worker has black hairs extensively intermixed with the yellow hairs on all terga.

\section{Distribution}

Bombus distinguendus is a widespread northern Palaearctic species (Fig. 2). P.H.W. has examined specimens from localities spanning Ireland in the west to Kolyma (Magadanskaya Oblast) in the east. Despite substantial collecting effort, there are no records of this species from the Kurile Islands (Ito and Sakagami 1980). Neither are there any records from Kamchatka in the faunal reviews by Bischoff (1930) or Ito and Kuranishi (2000). However, there is a record from Kamchatka shown on a map by Panfilov (1982, p. 27, map 149).

Attu Island was considered zoogeographically part of the Nearctic region by Wallace (1876) and is politically part of the New World. In view of this record for Attu Island, we might expect $B$. distinguendus to be found eventually in any similar habitats in eastern Kamchatka and in the Komandorskiye Ostrova (Commander Islands).

\section{Food plants}

The first bee recorded on 18 August 2002 was visiting Aconitum maximum Pallas ex DC (Ranunculaceae). This plant is native to the Aleutian Islands and is also known from eastern
Kamchatka, Komandorskiye Ostrova, Japan, China, and North America (Hulten 1947). It was not seen in the Massacre Bay area on the southwest side of Attu Island. This species is closely associated with the native Aleut peoples that inhabited many of the islands until the 1940s (including Attu and Rat islands). It contains the alkaloid pseudaconitine, a poison that the Aleuts used in whaling (Heizer 1938).

The bees recorded on 8-22 July 2003 were visiting Geranium erianthum DC (Geraniaceae) and Lupinus nootkatensis Donn ex Sims (Fabaceae). Both plants are native to the Aleutian Islands. Geranium erianthum is also native to eastern Kamchatka and North America (Bobrov 1949). Lupinus nootkatensis has been introduced widely in Japan, eastern North America, and western Europe. Both species appear to be absent from the tundra and are associated with disturbed areas, particularly along roads and around buildings.

All three plant species were present in Austin Cove on the northern side of Attu Island (Scoggan 1978; Kartesz and Meacham 1999). None of these plant species was present inside the Aleut villages, although they did occur within a few metres of some villages. Plant specimens are deposited in the R.L. McGregor Herbarium, University of Kansas.

\section{Key to females of Bombus (Fervidobombus) fervidus and the New World species of the subgenus Subterraneobombus}

To help identify other specimens, we have included a short key to females below. Bees can be identified to the subgenus Subterraneobombus using the key to subgenera by Michener (2000). The bees of this group from the New World all have the dorsal pubescence of the body predominantly pale, except for a black band between the wing bases and a small black "tail". They may have the metasoma brown, but they do not have red hair. The colour form of B. (Fervidobombus) fervidus (Fabr., 1798) from eastern North America is included in this key because it has a colour pattern very similar to that of the Subterraneobombus species.

1. Pubescence of metasomal tergum 4 pale and that of metasomal tergum 5 black, but if any pale hairs are present on tergum 5, they are confined to a narrow fringe along the posterior margin . . . . . . . . . 2

- Pubescence of metasomal terga 4 and 5 pale, but if any black hairs are present on tergum 5, they are confined to a patch intermixed in the middle of the anterior part . . . . . . . . . . . . . . . . . 3

2. Centre of clypeus covered with coarse punctures; pubescence of the head predominantly black . . . . eastern North American B. fervidus

- Centre of clypeus without coarse punctures, appearing smooth and shining; pubescence of the head predominantly yellow . . . . . . . . . . . . . . . . . . . . . . . B. borealis

3. Pale pubescence of head and of thoracic collar grey, pale pubescence of metasoma rusty brown, but if sometimes faded to yellow, then contrasting with the paler thoracic collar; surface of central half of tergum 6 coarsely granular . . . . . . . . . . . . . . . . . . . . . . . . . . . B. appositus

- Pale pubescence of head, thoracic collar, and metasoma straw yellow, without contrast; surface of central half of tergum 6 smooth and shining . . . . . . . . . . . . . . . . . . . . . B. distinguendus 


\section{References}

Bischoff, H. 1930. Entomologische Ergebnisse der schwedischen Kamtschatka Expedition 19201922. 29. Bombinae (Hymen.). Arkiv for Zoologi, 21: $1-6$.

Bobrov, E.G. 1949. Geraneaceae. In Flora of the USSR. XIV: Geraniales, Sapindales, Rhamnales. Edited by B.K. Shishkin and E.G. Bobrov. Izdatel'stvo Akademii Nauk USSR, Moscow. pp. 19-20.

Franklin, H.J. 1913. The Bombidae of the New World. Transactions of the American Entomological Society, 38: 177-486.

Handlirsch, A. 1888. Die Hummelsammlung des k. k. naturhistorischen Hofmuseums. Annalen des Naturhistorischen Museums in Wien, 3: 209-250.

Heizer, R.F. 1938. Aconite arrow poison in the Old and New World. Journal of the Washington Academy of Sciences, 28: 358-363.

Hulten, E. 1947. Flora of Alaska and Yukon: Dicotyledoneae (Myricales, Fagales, Urticales, Santalales, Polygonales, Centrospermae, Ranales). Gleerup, Lund.

Ito, M., and Kuranishi, R.B. 2000. Bumble bees (Hymenoptera: Apidae) occurring in the Kamchatka Peninsula and the North Kuril Islands. Natural History Research, 7: 281-289.

Ito, M., and Sakagami, S.F. 1980. The bumblebee fauna of the Kurile Islands (Hymenoptera: Apidae). Low Temperature Science, Series B: Biological Science, 38: 23-51.

Kartesz, J.T., and Meacham, C.A. 1999. Synthesis of the North American flora. Version 1.0 [CDROM]. North Carolina Botanical Garden, University of North Carolina, Chapel Hill, North Carolina.
Kearns, C.A., and Thomson, J.D. 2001. The natural history of bumblebees, a sourcebook for investigations. University Press of Colorado, Boulder, Colorado.

Michener, C.D. 2000. The bees of the world. John Hopkins University Press, Baltimore, Maryland.

Milliron, H.E. 1971. A monograph of the western hemisphere bumblebees (Hymenoptera: Apidae; Bombinae). I. The genera Bombus and Megabombus subgenus Bombias. Memoirs of the Entomological Society of Canada, 82: 1-80.

Milliron, H.E. 1973. A monograph of the western hemisphere bumblebees (Hymenoptera: Apidae; Bombinae). II. The genus Megabombus subgenus Megabombus. Memoirs of the Entomological Society of Canada, 89: 81-237.

Morawitz, F. 1869. Die Bienen des Gouvernements von St. Petersburg. Trudy Russkago Entomologicheskago Obshchestva, 6: 27-71.

Panfilov, D.V. 1982. Maps 147-150. In Provisional atlas of the insects of the European part of the U.S.S.R. Edited by K.B. Gorodkov. Leningrad.

Pittioni, B. 1942. Die boreoalpinen Hummeln und Schmarotzerhummeln (Hymen., Apidae, Bombinae). I. Teil. Izvestiya na Tsarskite prirodonauchni instituti v Sofiya, 15: 155-218.

Scoggan, H.J. 1978. The flora of Canada. National Museum of Natural Sciences, Ottawa, Ontario.

Wallace, A.R. 1876. The geographical distribution of animals, with a study of the relations of living and extinct faunas as elucidating the past changes of the Earth's surface. Macmillan and Co., London.

Williams, P.H. 1998. An annotated checklist of bumble bees with an analysis of patterns of description (Hymenoptera: Apidae, Bombini). Bulletin of the British Museum (Natural History), Entomology, 67: 79-152 [updated at www.nhm. ac.uk/entomology/bombus]. 